\title{
Impressions from Tunisia, Spring 2016
}

\author{
RAGNHILD J. ZORGATI (University of Oslo)
}

Key words: Sousse Spring Festival, Saxofans, music, terror, fear, safety, security, economy, religion, politics, cultural heritage, clothing, presence of the past

I sit in the Municipal Theater in Sousse, a city south of the Tunisian capital, thinking about the Bataclan Theatre in Paris and the National Theater in Oslo. I have never been to the Bataclan, only seen the pictures from that night of terror. But the seats in the municipal theater in Sousse remind me of the red plush seats in the National Theater in my hometown Oslo, although the decorations are less lavish overall here in Sousse and the ceiling less lofty. Today, it is the musical group Saxofans ${ }^{1}$ who enters the stage with their brass and percussion instruments - ranging from the saxophone, of course, to drums like the darbouka and table.

The drummer is the same tall, lanky guy whose body is rhythm and whom I watched together with friends and family at an outdoor concert in the Roman amphitheater of the Ribat in Sousse the summer of two years ago. Last year we abstained from any concerts. The memories of the massacre on the beach north of Sousse, only four kilometers south of our apartment still reverberated in the ground. Attending an outdoor concert was unthinkable then. But now we are here, less than a year later, attending an indoor concert. I wish I had eyes in my back that would enable me to see an eventual attacker. I do have nerves in my lower back, though, and they are tense. I have recorded all the emergency exits and I think of how I will run in zigzag to confuse any gunman should he appear.

After a while, I begin to engage with the music. The deep voice of the vocalist envelops my thoughts and my eyes notice her black boots and her black plain dress. The band consists in equal part of men and women on brass. On percussion there are only men. I can't avoid noticing that one of the women wears a miniskirt ${ }^{2}$ and that all the men are cool and relaxed, dressed casually in white shirts hanging loosely over their jeans. There are many photographers present; one of them is a young lady in Islamic garb-she is fashionable in a floor-length coat with a matching head scarf. Carrying a state-of-the-art camera, she takes many pictures. Maybe she is a local journalist? - For this is the closing concert of the $23^{\text {rd }}$ Sousse Spring Festival. We write March $26^{\text {th }}$, anno 2016.

1 Saxofans is a Tunisian brass band from Sousse, <https://www.facebook.com/saxofans-134750706543903/ about/?ref=page_internal>.

2 [Editor's note: Here and in the following, terms emphasized in bold indicate artifacts, roles and activities that with all probability will be of particular relevance for the In 2016 project's search for Gumbrecht'ian arrays, codes, and codes collapsed (cf. my Introduction to the present Living 2016 dossier). The emphasis is the editor's.] 
The concert is divided into three parts with three different vocalists. First out is a young lady performing within the Arabic song tradition. Her voice aspires towards that of a diva, an Umm Kulthoum or a Fairouz, but the expression is simpler. She also reminds me of Emel Mathlouthi ${ }^{3}$ - Mathlouthi whose magnificent song shook the audience at the Nobel Peace Prize Ceremony in Oslo last December (2015) as her voice brimmed with revolutionary force. She voiced the anger, the grief, the frustration, but also the empowerment of the young generation that ousted Ben Ali from power.

In Tunisia, the TV spectators were also preoccupied with Mathlouthi's dress. It was extremely low-cut, down to the navel-and she doesn't even have a bosom! We discussed this issue over a glass of tea during the spring holidays. Many of those present argued that she should have dressed in a more traditional gown to show her Tunisian identity; I affirmed that her choice of dress was bold but smart, because it challenged stereotypes in the global north about Islam and Arab (Muslim) women. Meanwhile, I pointed out that I had seen wedding dresses in Tunis with the same low-cut-so Mathlouthi's dress simply represented a new expression of an old, Tunisian tradition. The last discussant out wearing a hijab herself-stressed that the dress expressed Mathlouthi's own style and ought to be recognized and accepted as such.

Back to the concert: the music engages the audience and we let go of our worries; we clap the rhythm; some are dancing. I feel the beat in my bones. The second part of the concert becomes my favorite. This is extremely catchy music - traditional songs from the most remote inner areas of Tunisia. They are beloved melodies for most of those present, but in a rhythmic brass remake that speaks to my Norwegian ear. This music does not need an intellectual effort on my part to be liked. I don't need to educate my ear. This is music that talks directly to my body - could we call it world music?

During the third part of the concert, which is dominated by American pop and a vocalist known from Star Academy, my thoughts wander back to the past week.

In 2016, the Easter holiday coincided with the Tunisian spring holiday which always takes place during the two last weeks of March. And still it was so quiet, so few people $!^{4}$ In Port al-Kantaoui-a well-known tourist resort that was crowded by spring seeking northerners from Russia, France, England, Germany, Sweden and Norway six years ago, before the 2011 uprisings there were only a couple of Tunisian families strolling about. Some of them had been on a boat trip with one of the few catamarans or pirate ships that were still in business, most of the tourist boats having been brought into dock. An old couple, maybe from France, were the only foreigners that were left, except for me. The restaurants were empty during lunch time. At one we were served by seven waiters who, in addition to us, only had to take care of two other tables. We asked the owner how he got by: he said they were targeting the Tunisian market. Many hotels on the stretch from

3 Emel Mathlouthi is a Tunisian singer and composer known for her protest songs during the Arab uprisings, especially Kilmti hurra (my word is free) that she performed spontaneously in front of the crowd on the Habib Bourguiba Street in January 2011. In December 2015 she performed the same song at the Nobel Peace Concert in Oslo in honour of the Tunisian National Dialogue Quartet, <http:// emelmathlouthi.com/index.html>.

4 [Editor's note: highlighted because the deserted tourist resorts may become an array in the GUMBRECHT'ian sense] 
Kantaoui to Sousse seemed deserted; the less luxurious ones were derelict with broken windows and peeling plaster. Only the impressive Mövenpick keeps its façade. Here, at the Mövenpick, there are private guards every ten meters and black Mercedes in front of the entry. So there is still some money in this broken economy! - An economy ridden by unemployment rates reaching $25 \%$ per cent among the young people; a decline in investments and exports; a decline in the tourist industry with repercussions into other markets. The artist weaving her carpets has no customers and the farmer is not paid for his produce: parts of last summer's fruit and vegetables intended for the tourist market had to be thrown away, rotten. The prize of dates has sunk from 15 dinars per kilo in 2014 to 7 in 2016. But this does not help those families whose incomes are cut short. And the crisis is spreading. He who used to work in the hotel business and who paid for private tutoring for his kid does not pay any more: hence, another little, local business providing afterschool homework aid is also plunging.

The poor charcoal-burner becomes even poorer. He lives in a ramshackle shed at the outskirts of town in order to keep the glow alive during the night. His son, with a two-year high school education, takes casual jobs in the neighborhood, the dog barks towards strangers, and his wife sells bread to the family that has been a patron since time immemorial. But times are changing and the grand families do not rule alone any longer. The country is full of parvenus who made their fortunes under Ben Ali- of nouveaux riches with no education or manners, and utter disrespect for traditional means of conflict resolution: Where, forty years ago, the fathers brought their sons together to settle disputes within the walls of the family domain, the sons now bring their cases to court. May the judge be incorruptible!

On the wall of the charcoal-burner's shed there is a photo of the national patriarch Habib Bourguiba and the new President Beji Caïd Essebsi with the red Tunisian flag in the background. The photo is framed by two black banners with inscriptions in gold about Makkah and Medina. Nation and religion. There is no decultured Salafism aspiring towards the global umma within these walls, as far as I can tell. Olivier Roy's thesis about postmodern religion does not cover every situation. In this room one still knows one's place, one's nation and one's religion; but what about the son? Perhaps he has joined a neo-conservative, rebellious, Salafi group? Who knows?

Before the 2011 uprisings, there were no "Salafi looks" in the streets of Sousse and Tunis. Such an exaggerated and outré religious appearance would, with $100 \%$ certainty, attract the attention and in most cases the rough treatment of the police. Then came the uprisings; the Islamists came to power and religion was unleashed: hijabs came on, the niqab in some rare cases, beards grew, moustaches were trimmed or completely razed to imitate the Prophet Mohamed, trousers were shortened over the ankle, skirts were lengthened underneath it. The qamis was imported from Pakistan and Saudi, but the sneakers remained Nike - in original or fake versions, and one might sometimes have glimpsed a Louis Vuitton. That was in 2011-2012, the period that witnessed an increase in the economic crises; the incapacity of an inexperienced government to fulfill the hopes of its voters for economic development, dignity, and justice; and a public debate focusing on values and identity. In 2012-2013 everything escalated: two politicians were assassinated; there were terror attacks in the Chaambi Mountains; and Tunisian soldiers were killed on the border to Algeria. In 2014, new elections were held and with Beji Caïd Essebsi coming 
into office, Bourguiba's aura again illuminated the country. But the illumination was short lived: In March 2015, terrorists attacked the Bardo museum in Tunis, in June they came to the beach north of Sousse, and in September the presidential guard was the target in the middle of the capital. In March 2016, Daech attacked the frontier city of Ben Guerdane.

At that time the Salafi look was no longer tolerated. You were stopped at every police check point - one in every roundabout, approximately every five kilometers. It became impossible to be a taxi driver with a long beard. Young charismatic men with their eyes towards Makkah, spare time in the mosque, and with the Quran and hadith on their smartphones, were brought into custody, several times, until the chief inspector told his men that these youngsters were harmless, they were quietists - please do not bring them in anymore! Now, in 2016, the police men who under Ben Ali were perceived by a majority of Tunisians as the watchdogs of the regime are gaining status in many circles. The soldiers are heroes, and ads on national television feature a son greeting his father coming back from the front line. In these ads, the mother with rather short hair and no hijab represents the third member of the modern nuclear family. In the background floats the Tunisian flag.

Before going to Tunis in March 2016, I saw the play Klassen vår [Our School Class] at the National Theater in Oslo by the Polish playwright Tadeusz Słobodzianek. The play follows the life trajectories of a couple of class mates from a small village in Poland from the 1930 'ies until the 1980 'ies. It stages fifty years of war, terror, human cruelty and vulnerability in the most disturbing ways.

Listening to the music of the Saxofans in the Municipal Theater in Sousse I just make one wish: let 2016 be the year of rhythm and music!

(C) Ragnhild Zorgati, Associate Professor, History of Religions, University of Oslo, Norway

४ r.j.zorgati@ikos.uio.no 